\title{
Carotenoid Contents in Mammals I. Apodemus flavicollis and Clethrionomys glareolus
}

\author{
Bazyli CZECZUGA \& Elżbieta MALZAHN
}

\begin{abstract}
Czeczuga B. \& Malzahn E., 1980: Carotenoid contents in mammals, I. Apodemus flavicollis and Clethrionomys glareolus. Acta theriol., 25, 41: 501-509 [With 2 Tables \& 1 Figs.].

For A. flavicollis individuals examined, 10 carotenoids were identified in different parts of the body in males, and 14 in females. Total carotenoid contents in males varied from 0.198 (skin) to $0.874 \mu \mathrm{g} / \mathrm{g}$ (lungs), and in females from 0.510 (intestine) to $2.091 \mu \mathrm{g} / \mathrm{g}$ (liver). Fifteen carotenoids were identified in C. glareolus. The total content in males ranged from 0.316 (skin) to $1.542 \mu \mathrm{g} / \mathrm{g}$ (lungs), and in females - from 0.178 (skin) to $3.585 \mu \mathrm{g} / \mathrm{g}$ (liver).

[Dept. Biol., Medical Academy, Kilińskiego 1, 15-230 Białystok, and Mammals Res. Inst., PAS, 17-230 Białowieża]
\end{abstract}

\section{INTRODUCTION}

Carotenoids are some of the most commonly occurring pigments in plants and animals (I s l e r, 1971). They accompany chlorophyll pigments in green plants, and occur in the cells of both autotrophic and heterotrophic bacteria ( $\mathrm{Cz}$ e r pak \& $\mathrm{Cz}$ e c z u g a, 1979). In addition they are proper to both the lower fungi and pileus-bearing fungi ( $\mathrm{Czeczuga}$, 1978b). During the course of recent studies on the occurrence of carotenoids in representatives of different divisions of invertebrate animals, we became interested in the question of the presence of these pigments in different representatives of Mammalia, since these animals has not so far, apart from fragmentary reports (K a r rer \& J u cker, 1948), formed the subject of detailed studies. As is well known, carotenoids play an important part in the animal organism. As shown by numerous studies (D ingle \& L u cy, 1965), carotenoids primarily stabilize cell membranes, participate in oxidoreduction processes ( $\mathrm{Karnauchov}, 1973$ ) and, in relation to the organism as a whole, take part in, inter alia, the reproduction of animals (Goodwin, 1950), and also form a source of vitamin A which, as is well known, constitutes a biologically active substance of great importance to the animal organism. 
In view of the foregoing, we began studies on the contents of these pigments in different organs of selected species of mammals. We were additionally interested in the problem as to whether certain carotenoids are proper only to mammals. This is the first study of a series devoted to the occurrence of carotenoids in numerous species of mammals, in this particular paper dealing with individuals of such species as Apodemus flavicollis and Clethrionomys glareolus.

\section{MATERIAL AND METHODS}

Six individuals of both sexes of Apodemus flavicollis (Melchior, 1834), collected in May 1979 in the Białowieża National Park, and twenty individuals of Clethrionomys glareolus (Schreber, 1780) taken from animals bred in captivity at the Mammals Research Institute, PAS, at Białowieża, were used for the studies, which were concerned with the skin, muscles, liver, lungs and small intestine, separately for males and females.

The material collected was covered with $95 \%$ acetone in bottles, to which nitrogen was added, after which the bottles were kept in a refrigerator at a temperature of minus $4^{\circ} \mathrm{C}$. Before chromatographic identification, the corresponding parts of the body for each sex and species were combined, on account of the small amount of material at our disposal. Separation of the different carotenoid pigments was made by means of columnar and thin-layer chromatography. The material had previously been saponified with $10 \% \mathrm{KOH}$ in a nitrogen atmosphere at room temperature for 24 hours. After hydrolysis the extract was passed through the column filled with $\mathrm{Al}_{2} \mathrm{O}_{3}$. Length of column varied from 15 to $25 \mathrm{~cm}$ (from Quickfit, England). The different fractions were eluted, using different combinations of solvents. The eluent was next evaporated and the residue, after evaporation, was dissolved in the appropriate solvent ( $\mathrm{C} \mathrm{z} \mathrm{e-}$ czuga \& Czerpak, 1976), in order to plot the absorption curve, the maxima of which served, inter alia, to identify the various carotenoids. Identical carotenoids (from F. Hoffmann - La Roche, Basle) were used for identification of $\beta-, \gamma-$ carotene, canthaxanthin, lutein, zeaxanthin and astaxanthin. Absorption maxima were determined by using the Specol spectrophotometer.

In addition to columnar chromatography, the acetone extract obtained was separated into different bands, using thin-layer chromatography. For this purpose use was made of glass plates measuring $15 \times 40 \mathrm{~cm}$, which were covered with silicagel (from Merck), then transferring the acetone extract by means of a special micropipette on to the starting line, also using different solvent systems ( $\mathrm{Cz}$ eczuga \& Czerpak, 1976). $R_{f}$ value was next determined in accordance with generally accepted principles.

Identification of the various carotenoids was made on the basis of absorption maxima for the different fractions, $R_{f}$ value, the epoxide test and also the relations obtained for the epiphase and hypophase. Quantitative relations for the various carotenoids were determined by Davies' method ( $C$ zeczug a \& C zerp a k, 1976). 


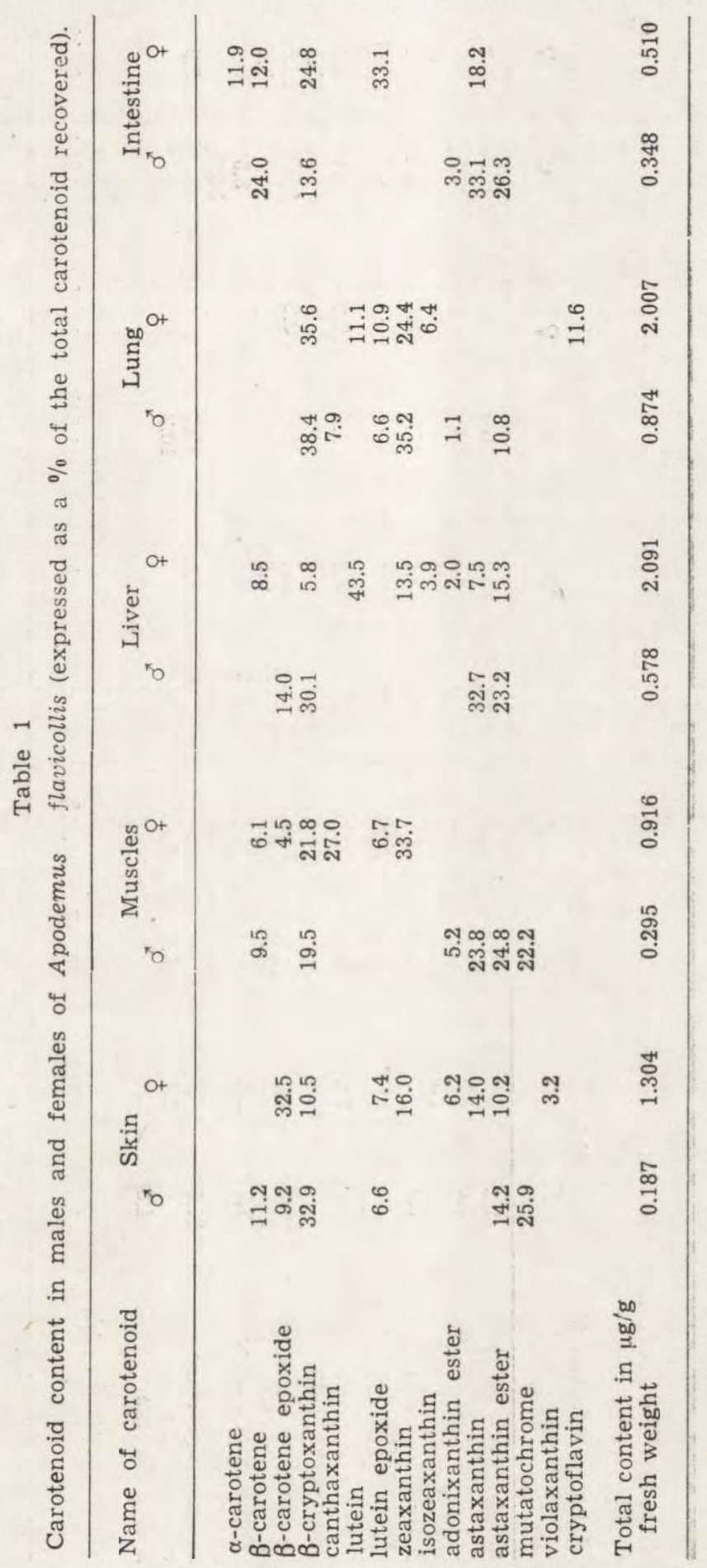


504

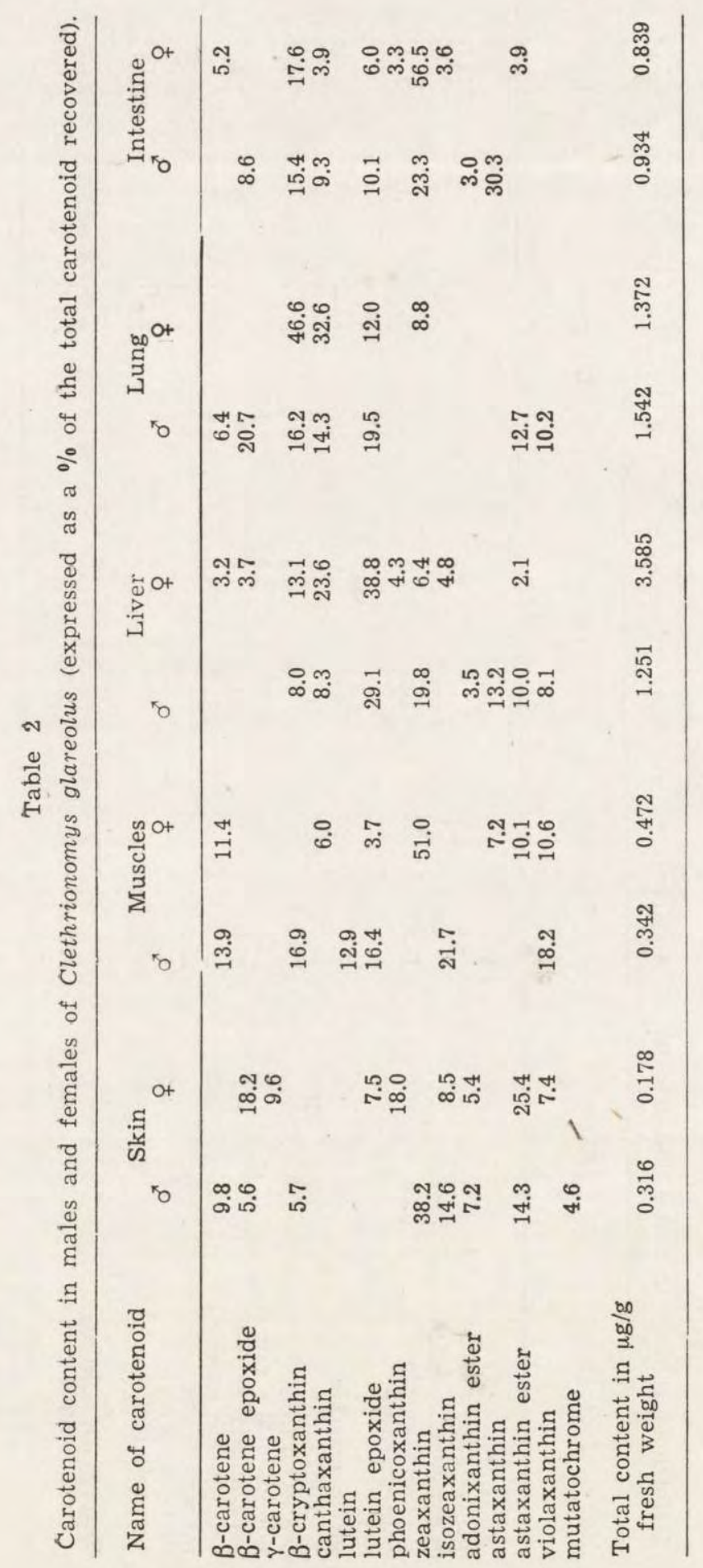




\section{RESULTS}

The results obtained by chromatographic analysis have been set out in Tables 1 and 2. For the A. flavicollis, 10 carotenoids were identified in different parts of the body in males, and 14 in females. Such carotenoidls as $\beta$-cryptoxanthin and astaxanthin ester in males of this species occurred in all the parts of the body analyzed, whereas the remaining carotenoids were found only in certain parts of the body. The dominating carotenoids included $\beta$-carotene (skin and lungs), and astaxanthin (both forms) in the remaining parts of the body. Total carotenoid contents in A. flavicollis males varied from 0.198 (skin) to $0.874 \mu \mathrm{g} / \mathrm{g}$ (lungs). $\alpha-$ carrotene, lutein, isozeaxanthin, violaxanthin and cryptoflavin were found onlly in female individuals of this species. The remaining carotenoids were the same as in males. Carotenoids occurring in the largest amounts

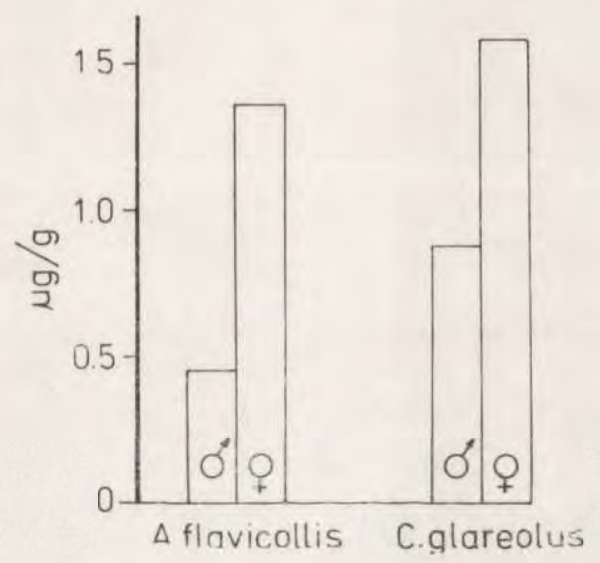

Fig. 1. Carotenoid contents in different sexes of the two species of rodents.

include $\beta$-carotene epoxide (skin), $\beta$-cryptoxanthin) (lungs), zeaxanthin (muscles), lutein (liver) and its epoxide form (intestine). The total carotenosid contents in females of $A$. flavicollis varied from 0.510 (intestine) to 2.091 $\mu \mathrm{g} / \mathrm{g}$ (liver).

The result of chromatographic analysis of individuals of $C$. glareolus have been set out in Table 2. Fifteen carotenoids were identified, the majority of which occurred in both females and males. Such carotenoids as; lutein and mutatochrome, however, were found only in males, and $\gamma$-icarotene and phoenicoxanthin only in females. The group of carotenoids ocscurring in the largest amounts in males include $\beta$-carotene epoxide (lungs), lutein epoxide (liver), zeaxanthin (skin), isozeaxanthin (muscles) and astaxanthin (intestine). In the case of females the dominating carote- 
noids are $\beta$-cryptoxanthin (lungs), lutein epoxide (liver), zeaxanthin (muscles and intestine) and astaxanthin ester (skin). The total carotenoid contents in males varied from 0.316 (skin) to $1.542 \mu \mathrm{g} / \mathrm{g}$ (lungs), and in females - from 0.178 (skin) to $3.585 \mu \mathrm{g} / \mathrm{g}$ (liver).

\section{DISCUSSION}

It is a known fact that animals are not able to produce carotenoids de novo, since this is proper only to plant organisms, animals obtaining them only together with their food, and being able to oxidise only certain of them. Studies with labelled $\mathrm{C}^{14}$ carotenoids $(\mathrm{H}$ a t a \& $\mathrm{H}$ a ta, 1973) showed that carotenoids ingested with food are assimilated in the small intestine, certain of them being next converted into vitamin $\mathrm{A}$ in the wall of the small intestine (Thompson et. al., 1949; Suzuki et al., 1963), or carried together with the blood to the various organs, in the cells of which they are deposited either in the form in which they were ingested together with food, or in a more oxidised state, in the form of a defined xanthophill ( $\mathrm{H} \mathrm{a} \mathrm{ta} \& \mathrm{H}$ a t a, 1973). In respect of the carotenoids found in individuals of the two species examined, the majority of identified carotenoids occur in larger or small quantities in different parts of higher plants (G o odwin, 1976; C z e c z u g a, 1978a). Only carotenoids such as canthaxanthin, phoenicoxanthin and astaxanthin occur very rarely in higher plants, although they have so far been shown to be present, even if only sporadically, in algae and fungi. On the other hand, in both invertebrates and vertebrates, they are exhibited relatively frequently, particularly astaxanthin, in both the pure and ester forms of this carotenoid (I s l e r, 1971). It must therefore be concluded that these carotenoids form in the study species by means of conversions of $\beta$-carotene or precursors of these carotenoids. Canthaxanthin and phoenicoxanthin lie in the path of conversions of $\beta$-carotene into astaxanthin, although, astaxanthin, judging by the list of carotenoids shown to be present in individuals of the two study species, may form in a different path of conversions of $\beta$-carotene or its derivatives such as $\beta$-cryptoxanthin, zeaxanthin or adonixanthin. All these carotenoids lying in the above-mentioned paths of $\beta$-carotene conversions, have been shown to be present in individuals of both the study species.

As is well known, canthaxanthin and astaxanthin belong to the group of ketocarotenoids (I s le r, 1971) which are capable of combining with proteins and forming carotenoid-protein complexes. Astaxanthin is most often included in the composition of these complexes, and canthaxanthin to a lesser degree. The biological function of the these complexes is 
varied. They impart colour to, for instance, the chitinous integument of numerous representatives of Arthropoda or other species of invertebrate animals ( $\mathrm{C}$ h e e s m a n et al., 1967). In addition carotenoid-protein complexes participate in control of protein configuration, endowing numerous animals with i.a. protective colouring ( $\mathrm{L} \mathrm{e}$ e, 1977), and they are also considered to play the part of a protective barrier against radiation, in particular against short rays. The presence in the mammals examined of carotenoids combining with proteins would suggest that these complexes are also present in other representatives of this class.

When comparison is made of total contents of carotenoids it is found that in the mammals examined, the liver and lungs contained more carotenoids than the other parts of the body. Greater carotenoid contents in the liver in comparison with other parts of the body has already been observed in numerous species of fish ( $\mathrm{Czeczuga}, 1979 \mathrm{a})$, in representatives of amphibians ( $\mathrm{Czeczuga}, 1980)$, in reptiles ( $\mathrm{Cze}$ c z $<$ g a, 1979c), and in some species of birds (Czeczuga, 1979b). In addition it is clear from comparison of mean carotenoid contents in individuals of different sex (Fig. 1) that females contain a far greater amount of them than males. Thus, while males of A. flavicollis contained only $0.456 \pm 0.042 \mu \mathrm{g} / \mathrm{g}$ of body weight, females of the same species contained at the same time $1.366 \pm 0.054 \mu \mathrm{g} / \mathrm{g}$. Similarly, the males of C. glareolus contained $0.877 \pm 0.032 \mu \mathrm{g} / \mathrm{g}$, and females $1.489 \pm 0.028 \mu \mathrm{g}$ of carotenoids/g of body weight. In this context it is worth recalling that a greater amount of carotenes is often observed in women in comparison with mean. B e s s e y et al. (1946) drew attention to this kind of phenomenon when analyzing $\beta$-carotene and vitamin A contents in serum from humans of different sex, and this has subsequently been confirmed by other researchers (Pearson, 1967; Modrze jewski, 1977). This may be a characteristic proper to all vertebrate animals.

\section{REFERENCES}

1. Bessey O. A., Lowry O. H., Brock M. J. \& Lopez J. A., 1946: The determination of vitamin A and carotene in small quantities of blood serum. J. Biol. Chem., 166: 177-181.

2. Che esman D. F., Le e W. L. \& Z a ga 1 s k y P. F., 1967: Carotenoproteins in invertebrates. Biol. Rev., 42: 131-160.

3. Czeczuga B., 1978a: The carotenoid content in certain plants from Abisko National Park (Swedish Lapland). Acta Soc. Bot. Pol., 47: 205-209.

4. $\mathrm{Czeczuga}$ B., 1978b: Investigations on carotenoids in fungi. V - Representatives on the Leccinum genus. Qual. Plant.-Pl. Fds. hum. Natr., 28: 197-201.

5. Czeczuga B., 1979a: Carotenoids in fish. XXII. Changes in carotenoids in Cyprinus carpio L. Hydrobiologia (Hague), 65: 233-240. 
6. Czeczuga B., 1979b: Carotenoids in the skin of certain species of birds. Comp. Biochem. Physiol., 62B: 107-109.

7. C z e c z g a B., 1979c: Carotenoids in some parts of certain species of lizards. Comp. Biochem. Physiol., 62B: 210-215.

8. Czeczuga B., 1980: Investigations on carotenoids in Amphibia. II. Carotenoids occurring in various parts of the body of certain species. Comp. Biochem. Physiol., 63B: 000-000.

9. Czeczuga B. \& Czerpak R., 1976: Carotenoids in fish. VII. The kind of food and the content of carotenoids and vitamin A in Carassius carassius (L.) and Leucaspius delineatus (Heck.). Acta Hydrobiol., 18: 1-21.

10. Czerpak R. \& Czeczuga B., 1979: Występowanie i biosynteza karotenoidów u bakterii. Wiad. Bot., 23: 73-88.

11. Dingle J. T. \& Lucy J. A., 1965: Vitamin A, carotenoids and cell function. Biol. Rev., 40: 422-461.

12. Good win T. W., 1950: Carotenoids and reproduction. Biol. Rev., 25: 391-413.

13. Goodwin T. W., 1976: Chemistry and biochemistry of plant pigments. Acad. Press, vol. 1: 1-870, vol. 2: 1-373. London - N. Y. - San Francisco.

14. H a t a M. \& H a t a M., 1973: Studies on astaxanthin formation in some freshwater fishes. Toh. J. Agricult. Res., 24: 192-196.

15. I s 1 e r O., 1971: Carotenoids. Birkhäuser Verlag: 1-932. Basle - Stuttgart.

16. Karnouchov V. N., 1973: Funkcji karotinoidov w kletkach žyvotnych. Nauka: 1-103, Moskva.

17. Karrer P. \& Jucker E., 1948: Caroticoide. Verlag Birkhäuser: 1-388. Basel.

18. L e e W. L., 1977: Carotenoproteins in animal coloration. Wiley: 1-242. New York.

19. Modrzejewski W., 1977: Witamina A i beta-karoten osocza w chorobie wieńcowej. Ph. D. Thesis. Medical Academy, Białystok: 1-104.

20. Pears on W. N., 1967: Blood and urinary vitamin levels as potential indices of body stores. Am. J. Clin. Natr., 20: 514-519.

21. Suzuki T., Koizumi I. \& Sahashi Y., 1963: $\beta$-carotene metabolism in intestinal tract. Mem. Tokyo Univ. Agric., 8: 11-27.

22. Thompson S. Y., Ganguly J. \& Kon S. K., 1949: The conversion of $\beta$-carotene to vitamin $\mathrm{A}$ in the intestine. Brit. J. Nutr., 3: 50-78.

Accepted, May 28, 1980.

Bazyli CZECZUGA i Elżbieta MALZAHN

ZAWARTOSC KAROTENOIDOW U SSAKOW.

I. APODEMUS FLAVICOLLIS I CLETHRIONOMYS GLAREOLUS

\section{Streszczenie}

Autorzy stosując kolumnowa i cienkowarstwową chromatografię badali występowanie i zawartość poszczególnych karotenoidów w skórze, mięśniach, wątrobie, płucach i jelitach u osobników obu płci A. flavicollis oraz C. glareolus. 
Jeśli chodzi o osobniki $A$. flavicollis to ustalono obecność takich karotenoidów jak $\alpha$-, $\beta$-carotene, $\beta$-carotene epoxide, $\beta$-cryptoxanthin, canthaxanthin, lutein, lutein epoxide, zeaxanthin, isozeaxanahin, adonixanthin ester, astaxanthin, astaxanthin ester, violaxanthin, mutatochrome oraz cryptoflavin. Ogólna zawartość karotenoidów wahała się $w$ granicach $0,187-0,874 \mu \mathrm{g} / \mathrm{g} u$ samców oraz $0,510-2,091 \mu \mathrm{g} / \mathrm{g}$ ciężaru ciała u samic.

Co zaś się tyczy badanych osobników C. glareolus to stwierdzono obecność z kolei takich karotenoidów jak $\beta$-, $\gamma$-carotene, $\beta$-carotene epoxide, $\beta$-cryptoxanthin, canthaxathin, lutein, lutein epoxide, phoenicoxanthin, zeaxanthin, isozeaxanthin, adonixanthin ester, astaxanthin, astaxanthin ester, violaxanthin oraz mutatochrome. Ogólna ich zawartość wahała się w granicach $0,316-1,542 \mu \mathrm{g} / \mathrm{g}$ u samców i $0,178-3,585 \mu \mathrm{g} / \mathrm{g}$ ciężaru ciała u samic.

Srednia zawartość karotenoidów u samic obu gatunków była większa aniżeli u samców. 